\title{
Prevalence and Antimicrobial Susceptibility of Vancomycin Resistant Staphylococci in an Egyptian University Hospital
}

\section{Tarek El-Said El-Banna, Fatma Ibrahim Sonbol, Ahmed Ahmed Abd El-Aziz and Engy El-Ekhnawy*}

Faculty of Pharmacy, Department of Pharmaceutical Microbiology, Tanta University, Egypt

*Corresponding author: Engy El-Ekhnawy, Faculty of Pharmacy, Department of Pharmaceutical Microbiology, Tanta University, Egypt, Tel: 040 3336007; Fax: 040 3335466; E-mail: Engy.elekhnawy2020@gmail.com

Rec: January 02, 2018, Acc: February 09, 2018, Pub: February 13, 2018

Copyright: (c) 2018 El-Said El-Banna T, et al.This is an open-access article distributed under the terms of the Creative Commons Attribution License, which permits unrestricted use, distribution, and reproduction in any medium, provided the original author and source are credited.

\begin{abstract}
Staphylococci can cause many nosocomial and community acquired infections with high rates of morbidity and mortality. The large scale of spread of resistance to vancomycin and other antibiotics has been perceived as a fearsome threat to the already challenging therapy of staphylococci. A total of 982 clinical samples were obtained from different departments of Tanta university hospital. Microscopical examination and standard biochemical tests revealed that 437 isolates were staphylococci.
\end{abstract}

Resistance to vancomycin was determined using disk diffusion and agar dilution methods which revealed that 89 were vancomycin resistant staphylococci (VRS). The susceptibility of VRS isolates to 15 different antimicrobial agents was performed using agar dilution method. All VRS isolates were multidrug resistant (MDR).

Polymerase chain reaction (PCR) studies were performed on selected staphylococci isolates with different vancomycin MICs ranging from 2 to $512 \mu \mathrm{g} / \mathrm{ml}$ for detection of vancomycin resistance genes (van genes). The vanA gene was detected in VRS isolates only with vancomycin MICs from 32 to $512 \mu \mathrm{g} / \mathrm{ml}$. Neither vanB nor vanC gene was detected.

$\beta$-Lactamase production by VRS isolates was investigated. A total of $88.7 \%$ of isolates produced $\beta$-lactamase enzyme. Disk approximation test was performed on all VRS isolates that were resistant to erythromycin and sensitive to clindamycin. Out of the 29 isolates on which the test was performed, $24(82.8 \%)$ tested positive. Ciprofloxacin resistant VRS isolates were selected to study the presence of efflux mechanism of resistance. All the tested isolates were efflux positive.

The VRS isolates in hospitals as well as in community are alarming to the clinicians and multi drug resistance in these isolates is very dangerous. In this study we tried to investigate the prevalence of VRS isolates in Tanta and to determine their antibiotic susceptibility.

Keywords Antimicrobial; $\beta$-Lactamase; Efflux; MIC; Multidrug; PCR; Resistance; Staphylococci; Vancomycin; VRS

\section{Introduction}

Staphylococci have been recognized as an important cause of human diseases for more than 100 years [1]. It is recognized as a cause of a lot of infections which range from minor skin infections to devastating septicemia and endocarditis [2]. Moreover, antibiotic resistance has complicated the treatment procedures. The resistance causes more costs and it may result in failure of treatment. The first clinical isolate of vancomycin resistant Staphylococcus aureus (VRSA) was isolated in japan in 1997. Since then, vancomycin resistant staphylococci (VRS) have spread with very high rapidity and are now detected in hospitals in most countries [3]. Resistance among VRS isolates to multiple classes of antimicrobials is a major threat to patient care. This has stimulated more efforts to understand the mechanisms of antimicrobial resistance. It was found that this problem has been attributed in part to inappropriate use of antimicrobials and failure among healthcare providers to comply with infection control precautions [4]. Significant controversy still exists regarding the current and the future role of vancomycin in the treatment of serious staphylococcal infections. It was of interest to investigate VRS isolates recovered from Tanta area, antimicrobial susceptibility testing, polymerase chain reaction (PCR) for analysis of van genes, $\beta$ lactamase production, inducible clindamycin resistance, efflux mechanism of resistance was analyzed in this study. Although there is a considerable progress in the understanding of vancomycin resistance in staphylococci, more research should be done to find the ideal treatment and control of multi drug resistant VRS infections.

\section{Materials and Methods}

\section{Collection and transport of samples}

Clinical specimens including blood, sputum, urine, nasal swaps and wound pus were collected from patients admitted to different departments of Tanta university hospital. Samples were transported to microbiology laboratory within $1 \mathrm{hr}$. 


\section{Identification of staphylococci}

The specimen of each patient was cultured into nutrient broth and incubated overnight at $37^{\circ} \mathrm{C}$. Then, $10 \mu \mathrm{l}$ of the broth was plated on agar plates containing horse blood $5 \% \mathrm{v} / \mathrm{v}$ and mannitol salt agar (MSA) media then incubated at $37^{\circ} \mathrm{C}$ for $24 \mathrm{~h}$. Identification of the developed colonies was depended on morphology and biochemical tests according to standard criteria [5].

\section{Screening of VRS isolates}

Kirby-Bauer disk diffusion method was carried out using vancomycin disk $(30 \mu \mathrm{g})$ (Oxoid). The testing conditions and interpretation of results was done according to CLSI [6] criteria. Briefly, a swab was dipped into the bacterial suspension and spread over the dried agar plate. Three to five min after the surface of agar plate has been inoculated; the vancomycin disk was applied and gently pressed onto the agar using sterile forceps. The plates were inverted and incubated at $37^{\circ} \mathrm{C}$ for $24 \mathrm{hrs}$. Zone of growth inhibition around the disc was measured in 2 different directions. The average of the zone diameters was translated into pattern of antimicrobial sensitivity (sensitive, intermediate or resistant). The isolate is considered resistant when the inhibition zone diameter (IZ) $\leq 10 \mathrm{~mm}$; intermediate when IZ form 11 to $13 \mathrm{~mm}$ and sensitive when the IZ $\geq 14$.

\section{Antimicrobial sensitivity testing}

MICs of 15 different antimicrobial agents including: ampicillin, oxacillin, ampicillin/sulbactam, cefotaxime, gentamicin, amikacin, rifampicin, chloramphenicol, sulphonamide/trimethoprime, erythromycin, azithromycin, clindamycin, ciprofloxacin, linezolid and vancomycin (Oxoid) against vancomycin resistant staphylococci isolates were determined by agar dilution method according to the procedure described by CLSI [6] as follow, aliquot of the prepared suspension of each isolate was transferred by automatic pipette to a certain well of a sterile multiinoculator in the seed plates (containing different concentrations of antimicrobial agents) according to a configuration of a record key. After (18-24) hrs of incubation at $37^{\circ} \mathrm{C}$, the presence of growth on the plate containing the lowest concentration of the given antimicrobial agent indicates the minimum inhibitory concentration (MIC) value of this antimicrobial against the tested isolate.

\section{Detection of vancomycin resistance determinants (van genes) by PCR}

DNA isolation: The test inoculum was prepared by inoculating 2 to 3 well isolated colonies into $4 \mathrm{ml}$ of BHI broth (Hi-Media) and incubated overnight at $37^{\circ} \mathrm{C}$. DNA was extracted using Genomic DNA extraction kit (Thermo SCIENTIFIC, USA). Forwad primer for vanA gene 5'-CATGAATAGAATAAAAGTTGCAATA and reverse primer 5'-CCCCTTTAACGCTAATACGACGATCAA according to [7]. Forward primer for $\operatorname{vanB}$ gene 5'-ACGGAATGGGAAGCCGA and reverse 5'-TGCACCCGATTTCGTTC. Forward primers for vanC gene 5'-ATGGATTGGTACTGGTAT and reverse 5'TAGCGGGAGTGACCAGTAA. Primers for $\operatorname{van} B$ and $\operatorname{van} C$ genes according to Bhatt et al. [8].

A $25 \mu \mathrm{l}$ reaction volume consisting of $12.5 \mu \mathrm{l}$ master mix, $2.5 \mu \mathrm{l}$ primer mix $(0.2 \mu \mathrm{M}$ of each primer) and $3 \mu \mathrm{l}$ of DNA template and $7 \mu \mathrm{l}$ of RNase free water was prepared. DNA samples were subjected to thermocycling conditions with initial inactivation step $\left(95^{\circ} \mathrm{C}, 15 \mathrm{~min}\right)$ with three step cycling condition of denaturation $\left(94^{\circ} \mathrm{C}, 30 \mathrm{sec}\right)$, annealing $\left(60^{\circ} \mathrm{C}, 90 \mathrm{sec}\right)$ and extension $\left(72^{\circ} \mathrm{C}, 90 \mathrm{sec}\right)$ for $35 \mathrm{cycles}$ with final extension $\left(72^{\circ} \mathrm{C}, 10 \mathrm{~min}\right)$ and soak at $4^{\circ} \mathrm{C}$. Then $5 \mu \mathrm{l}$ of amplified products were mixed with $2 \mu$ of ethidium bromide (Fermentas) and loaded on a $1.8 \%$ agarose gel (Amresco) along with the $1 \mathrm{~kb}$ DNA Ladder (Fermentas) and electrophoresis at 100 volt for $60 \mathrm{~min}$ and visualized under UV transilluminator (Bio-Doc analyzer, Biometra).

\section{Detection of $\beta$-lactamase production}

It was carried out using iodometric overlay method as described by Abo-Kamar and Shohayeb [9]. VRS isolates were grown first onto plates containing $2 \mu \mathrm{g} / \mathrm{ml}$ penicillin $\mathrm{G}$, then they were tooth picked onto the surface of nutrient agar plates. After overnight incubation at $37^{\circ} \mathrm{C}$, the plates were over laid with $1 \%$ molten agarose containing $0.2 \%$ soluble starch, $1 \%$ penicillin G. They were incubated for $15 \mathrm{~min}$ at room temperature and iodine solution was poured onto the agar plates to cover it uniformly, after $10 \mathrm{sec}$, the residual iodine solution was damped out and the plates were incubated at room temperature until discoloration zones appeared around $\beta$-lactamase producing colonies within $5 \mathrm{~min}$.

\section{Detection of inducible clindamycin resistance among VRS isolates using the disk approximation test (D-test)}

It was carried out according to the method reported by Fiebelkorn et al. [10]. A 15- $\mu$ g erythromycin disk was placed $20 \mathrm{~mm}$ apart from a disk containing $2 \mu \mathrm{g}$ clindamycin. The procedures of disk diffusion testing were performed according to CLSI [6]. Positive result was recorded if zone of inhibition of clindamycin was flattened in the area adjacent to erythromycin disk giving a $\mathrm{D}$ shape to the zone (D-zone effect).

\section{Studying efflux mechanism in ciprofloxacin resistant VRS isolates}

Efflux of ethidium bromide was measured fluorimetrically as described by Mullin et al. [11]. with some modifications. In nutrient broth containing $20 \mu \mathrm{g} / \mathrm{ml}$ reserpine (efflux inhibitor) and $0.5 \%$ glucose, overnight culture of bacterial cells was loaded with ethidium bromide $(10 \mu \mathrm{g} / \mathrm{ml})$ for $20 \mathrm{~min}$. Then, cells were centrifuged, and the pellet was resuspended to an OD600 of 0.2 in fresh growth medium alone or in presence of reserpine for $10 \mathrm{~min}$. Release of ethidium bromide from the cells was monitored by the decrease in fluorescence of cell suspension at excitation $\lambda$ of $600 \mathrm{~nm}$ and an emission $\lambda$ of 530 $\mathrm{nm}$.

\section{Results}

A total of 982 clinical samples were collected from different departments of Tanta university hospital during the period from October 2011 to August 2012. All samples were cultured on nutrient agar and examined microscopically. Gram +ve bacteria were subjected to biochemical identification which revealed that 437 isolates were staphylococci. A total of $401(91.8 \%)$ of these isolates were $S$. aureus and the remaining $36(8.2 \%)$ were coagulase negative staphylococci (CoNS). 
Citation: El-Said El-Banna T, Sonbol FI, Abd El-Aziz AA, El-Ekhnawy E (2018) Prevalence and Antimicrobial Susceptibility of Vancomycin Resistant Staphylococci in an Egyptian University Hospital. J Med Microb Diagn 7: 272. doi:10.4172/2161-0703.1000272

Page 3 of 8

\section{Preliminary screening of vancomycin resistance among Staphylococci isolates}

All the recovered (437) staphylococci isolates were subjected to disk agar diffusion method for preliminary screening of vancomycin resistant staphylococci (VRS) and 89 (20.3\%) VRS isolates were detected. Distribution of vancomycin resistant $S$. aureus $(20.1 \%)$ and vancomycin resistant CoNS (0.2\%) among the recovered staphylococci isolates is shown in Figure 1.

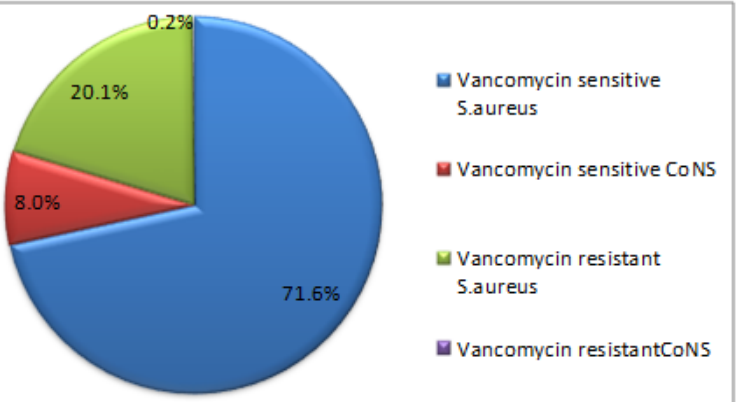

Figure 1: Pie chart showing distribution of vancomycin resistant $S$. aureus and vancomycin resistant CoNS among the recovered staphylococci isolates.

\section{Antimicrobial sensitivity testing}

The susceptibility of 89 VRS isolates to 15 different antimicrobial agents was performed using agar dilution method as shown in Figure 2. The antimicrobial resistance pattern is shown in Table 1 in supplemental information. In this study all VRS isolates exhibited MDR character according to Magiorakos et al. [12].

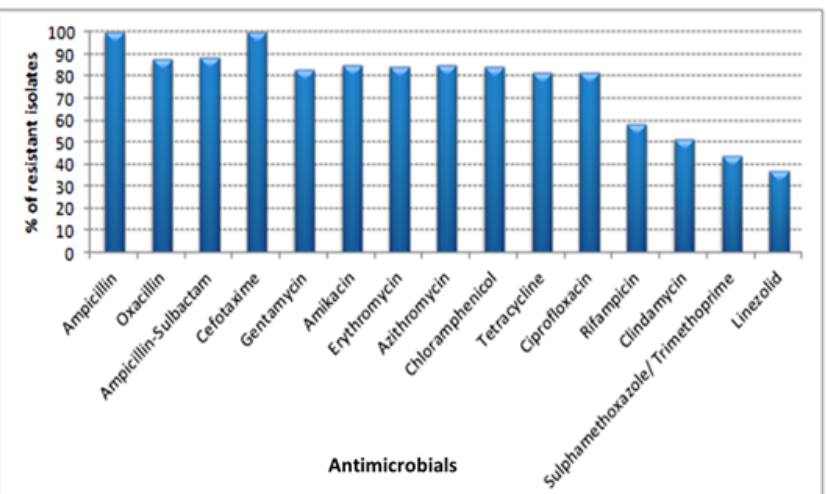

Figure 2: Histogram showing resistance of VRS isolates to the tested antimicrobial drugs.

\begin{tabular}{|l|l|l|l|}
\hline $\begin{array}{l}\text { No. of } \\
\text { markers }\end{array}$ & $\begin{array}{l}\text { Pattern } \\
\text { code }\end{array}$ & $\begin{array}{l}\text { Antimicrobial resistance } \\
\text { pattern* }\end{array}$ & $\begin{array}{l}\text { No. (\%) } \\
\text { of } \\
\text { isolates }\end{array}$ \\
\hline 10 & PI a & $\begin{array}{l}\text { AMP-OXA-AMS-CTX-GEN-AZI- } \\
\text { CHL-TETCIP- } \\
\text { VAN }\end{array}$ & $2(2.2 \%)$ \\
\hline
\end{tabular}

\begin{tabular}{|c|c|c|c|}
\hline & $\mathrm{Pl} \mathrm{b}$ & $\begin{array}{l}\text { AMP-OXA-AMS-CTX-AMK-AZI- } \\
\text { CHL-TETCIP- } \\
\text { VAN }\end{array}$ & $1(1.1 \%)$ \\
\hline & $\mathrm{PI} \mathrm{c}$ & $\begin{array}{l}\text { AMP-CTX-AMK-AZI-CHL-TET- } \\
\text { CIP-RIFSXT- } \\
\text { VAN }\end{array}$ & $1(1.1 \%)$ \\
\hline & PId & $\begin{array}{l}\text { AMP-CTX-GEN-AMK-AZI-CHL- } \\
\text { TET-CIPSXT- } \\
\text { VAN }\end{array}$ & $1(1.1 \%)$ \\
\hline \multirow[t]{7}{*}{11} & Pll a & $\begin{array}{l}\text { AMP-OXA-AMS-CTX-GEN-AMK- } \\
\text { ERYAZI- } \\
\text { CHL-CIP-VAN }\end{array}$ & $3(3.3 \%)$ \\
\hline & PII b & $\begin{array}{l}\text { AMP-OXA-AMS-CTX-GEN-AZI- } \\
\text { CHL-TETCIP- } \\
\text { RIF-VAN }\end{array}$ & $2(2.2 \%)$ \\
\hline & PII c & $\begin{array}{l}\text { AMP-OXA-AMS-CTX- GEN-AZI- } \\
\text { CHL-TETCIP- } \\
\text { SXT-VAN }\end{array}$ & $1(1.1 \%)$ \\
\hline & Pll d & $\begin{array}{l}\text { AMP-OXA-AMS-CTX-AMK-ERY- } \\
\text { AZICHL- } \\
\text { TET-CIP-VAN }\end{array}$ & $2(2.2 \%)$ \\
\hline & Pll e & $\begin{array}{l}\text { AMP-CTX-GEN-AMK-AZI-CHL- } \\
\text { TET-CIPRIF- } \\
\text { SXT-VAN }\end{array}$ & $4(4.4 \%)$ \\
\hline & PII $f$ & $\begin{array}{l}\text { AMP-CTX-GEN-AMK-ERY-CHL- } \\
\text { TET-CIPCLI- } \\
\text { SXT-VAN }\end{array}$ & $2(2.2 \%)$ \\
\hline & Pll g & $\begin{array}{l}\text { AMP-CTX-AMK-ERY-CHL-TET- } \\
\text { CIP-RIFCLI- } \\
\text { SXT-VAN }\end{array}$ & $1(1.1 \%)$ \\
\hline \multirow[t]{7}{*}{12} & PIII a & $\begin{array}{l}\text { AMP-OXA-AMS-CTX-GEN-AMK- } \\
\text { ERYAZI- } \\
\text { CHL-TET-CLI-VAN }\end{array}$ & $3(3.3 \%)$ \\
\hline & PIII b & $\begin{array}{l}\text { AMP-OXA-AMS-CTX-GEN-AMK- } \\
\text { ERYAZI- } \\
\text { TET-CIP-CLI-VAN }\end{array}$ & $3(3.3 \%)$ \\
\hline & PIII c & $\begin{array}{l}\text { AMP-OXA-AMS-CTX-GEN-AMK- } \\
\text { ERYAZI- } \\
\text { TET-CIP-SXT-VAN }\end{array}$ & $1(1.1 \%)$ \\
\hline & PIII d & $\begin{array}{l}\text { AMP-OXA-AMS-CTX-GEN-AMK- } \\
\text { ERYAZI- } \\
\text { CHL-CIP-RIF-VAN }\end{array}$ & $1(1.1 \%)$ \\
\hline & PIII e & $\begin{array}{l}\text { AMP-OXA-AMS-CTX-GEN-AMK- } \\
\text { ERYAZI- } \\
\text { CHL-CIP-SXT-VAN }\end{array}$ & $3(3.3 \%)$ \\
\hline & PIII $f$ & $\begin{array}{l}\text { AMP-OXA-AMS-CTX-GEN-AMK- } \\
\text { ERYAZI- } \\
\text { TET-CIP-RIF-VAN }\end{array}$ & $1(1.1 \%)$ \\
\hline & PIII g & $\begin{array}{l}\text { AMP-OXA-AMS-CTX-AMK-ERY- } \\
\text { AZICHL- } \\
\text { TET-CIP-RIF-VAN }\end{array}$ & $5(5.6 \%)$ \\
\hline
\end{tabular}


Citation: El-Said El-Banna T, Sonbol FI, Abd El-Aziz AA, El-Ekhnawy E (2018) Prevalence and Antimicrobial Susceptibility of Vancomycin Resistant Staphylococci in an Egyptian University Hospital. J Med Microb Diagn 7: 272. doi:10.4172/2161-0703.1000272

Page 4 of 8

\begin{tabular}{|c|c|c|c|}
\hline & PIII h & $\begin{array}{l}\text { AMP-OXA-AMS-CTX-GEN-ERY- } \\
\text { CHL-TETCIP- } \\
\text { CLI-SXT-VAN }\end{array}$ & $2(2.2 \%)$ \\
\hline & PIII i & $\begin{array}{l}\text { AMP-OXA-AMS-CTX-GEN-ERY- } \\
\text { CHL-CIPRIF- } \\
\text { CLI-SXT-VAN }\end{array}$ & $1(1.1 \%)$ \\
\hline & PIII j & $\begin{array}{l}\text { AMP-CTX-GEN-AMK-ERY-CHL- } \\
\text { TET-CIPRIF- } \\
\text { CLI-SXT-VAN }\end{array}$ & $1(1.1 \%)$ \\
\hline 13 & $\mathrm{PVI}$ a & $\begin{array}{l}\text { AMP-OXA-AMS-CTX-GEN-AMK- } \\
\text { ERYAZI- } \\
\text { CHL-TET- CLI- LNZ-VAN }\end{array}$ & $3(3.3 \%)$ \\
\hline & PVI b & $\begin{array}{l}\text { AMP-OXA-AMS-CTX-GEN-AMK- } \\
\text { ERYAZI- } \\
\text { CHL-TET-RIF-CLI-VAN }\end{array}$ & $4(4.4 \%)$ \\
\hline & PVI c & $\begin{array}{l}\text { AMP-OXA-AMS-CTX-GEN-AMK- } \\
\text { ERYAZI- } \\
\text { CHL-TET-CIP-CLI-VAN }\end{array}$ & $1(1.1 \%)$ \\
\hline & PVId & $\begin{array}{l}\text { AMP-OXA-AMS-CTX-GEN-AMK- } \\
\text { ERYAZI- } \\
\text { TET-CIP-CLI-LNZ-VAN }\end{array}$ & $1(1.1 \%)$ \\
\hline & PVI e & $\begin{array}{l}\text { AMP-OXA-AMS-CTX-GEN-AMK- } \\
\text { ERYAZI- } \\
\text { TET-CIP-RIF-SXT-VAN }\end{array}$ & $1(1.1 \%)$ \\
\hline & PVIf & $\begin{array}{l}\text { AMP-OXA-AMS-CTX-GEN-AMK- } \\
\text { ERYAZI- } \\
\text { TET-CIP-RIF-LNZ-VAN }\end{array}$ & $3(3.3 \%)$ \\
\hline & PVI g & $\begin{array}{l}\text { AMP-OXA-AMS-CTX-GEN-AMK- } \\
\text { ERYAZI- } \\
\text { CHL-CIP-SXT-LNZ-VAN }\end{array}$ & $2(2.2 \%)$ \\
\hline & PVI h & $\begin{array}{l}\text { AMP-OXA-AMS-CTX-GEN-AMK- } \\
\text { AZICHL- } \\
\text { TET-CIP-RIF-LNZ-VAN }\end{array}$ & $2(2.2 \%)$ \\
\hline & PVI i & $\begin{array}{l}\text { AMP-OXA-AMS-CTX-AMK-ERY- } \\
\text { AZICHL- } \\
\text { TET-CIP-RIF-SXT-VAN }\end{array}$ & $1(1.1 \%)$ \\
\hline & $P V I j$ & $\begin{array}{l}\text { AMP-OXA-AMS-CTX-AMK-ERY- } \\
\text { AZICHL- } \\
\text { TET-CIP-SXT-LNZ-VAN }\end{array}$ & $1(1.1 \%)$ \\
\hline & PVI k & $\begin{array}{l}\text { AMP-OXA-AMS-CTX-AMK-ERY- } \\
\text { AZICHL- } \\
\text { TET-CIP-RIF-LNZ-VAN }\end{array}$ & $1(1.1 \%)$ \\
\hline & PVII & $\begin{array}{l}\text { AMP-OXA-AMS-CTX-GEN-ERY- } \\
\text { CHL-TETCIP- } \\
\text { CLI-SXT-LNZ-VAN }\end{array}$ & $2(2.2 \%)$ \\
\hline & PVI m & $\begin{array}{l}\text { AMP-OXA-AMS-CTX-GEN-ERY- } \\
\text { CHL-CIPRIF- } \\
\text { CLI-SXT-LNZ-VAN }\end{array}$ & $1(1.1 \%)$ \\
\hline & PVIn & $\begin{array}{l}\text { AMP-OXA-AMS-CTX-AMK-AZI- } \\
\text { CHL-TETCIP- } \\
\text { RIF-SXT-LNZ-VAN }\end{array}$ & $1(1.1 \%)$ \\
\hline
\end{tabular}

\begin{tabular}{|c|c|c|c|}
\hline & PVIo & $\begin{array}{l}\text { AMP-CTX-GEN-AMK-ERY-CHL- } \\
\text { TET-CIPRIF- } \\
\text { CLI-SXT-LNZ-VAN }\end{array}$ & $1(1.1 \%)$ \\
\hline \multirow[t]{12}{*}{14} & PV a & $\begin{array}{l}\text { AMP-OXA-AMS-CTX-GEN-AMK- } \\
\text { ERYAZI- } \\
\text { CHL-TET-CIP-RIF-CLI-VAN }\end{array}$ & $5(5.6 \%)$ \\
\hline & $\mathrm{PV} b$ & $\begin{array}{l}\text { AMP-OXA-AMS-CTX-GEN-AMK- } \\
\text { ERYAZI- } \\
\text { CHL-TET-RIF-CLI-LNZ-VAN }\end{array}$ & $4(4.4 \%)$ \\
\hline & $\mathrm{PV} \mathrm{c}$ & $\begin{array}{l}\text { AMP-OXA-AMS-CTX-GEN-AMK- } \\
\text { ERYAZI- } \\
\text { CHL-TET-CLI-SXT-LNZ-VAN }\end{array}$ & $1(1.1 \%)$ \\
\hline & \multirow[t]{2}{*}{$P V d$} & $\begin{array}{l}\text { AMP-OXA-AMS-CTX-GEN-AMK- } \\
\text { ERYAZI- } \\
\text { CHL-TET-CIP-CLI-LNZ-VAN }\end{array}$ & $1(1.1 \%)$ \\
\hline & & $\begin{array}{l}\text { AMP-OXA-AMS-CTX-GEN-AMK- } \\
\text { ERYAZI- } \\
\text { CHL-CIP-RIF-CLI-LNZ-VAN }\end{array}$ & $2(2.2 \%)$ \\
\hline & PVe & $\begin{array}{l}\text { AMP-OXA-AMS-CTX-GEN-AMK- } \\
\text { ERYAZI- } \\
\text { TET-CIP-CLI-SXT-LNZ-VAN }\end{array}$ & $1(1.1 \%)$ \\
\hline & $P V f$ & \multirow{2}{*}{$\begin{array}{l}\text { AMP-OXA-AMS-CTX-GEN-AMK- } \\
\text { ERYAZI- } \\
\text { CHL-CIP-RIF-SXT-LNZ-VAN }\end{array}$} & \multirow[t]{2}{*}{$1(1.1 \%)$} \\
\hline & $\mathrm{PV} g$ & & \\
\hline & \multirow[t]{2}{*}{$\mathrm{PVh}$} & $\begin{array}{l}\text { AMP-OXA-AMS-CTX-GEN-AMK- } \\
\text { ERYAZI- } \\
\text { TET-CIP-RIF-SXT-LNZ-VAN }\end{array}$ & $3(3.3 \%)$ \\
\hline & & $\begin{array}{l}\text { AMP-OXA-AMS-CTX-GEN-ERY- } \\
\text { AZI-CHLTET- } \\
\text { CIP-RIF-CLI-SXT-VAN }\end{array}$ & $1(1.1 \%)$ \\
\hline & $P V i$ & \multirow{2}{*}{$\begin{array}{l}\text { AMP-AMS-CTX-GEN-AMK-ERY- } \\
\text { CHLTET- } \\
\text { CIP-RIF-CLI-SXT-LNZ-VAN }\end{array}$} & \multirow[t]{2}{*}{$1(1.1 \%)$} \\
\hline & $P V j$ & & \\
\hline \multirow[t]{2}{*}{15} & $\mathrm{PVI} a$ & $\begin{array}{l}\text { AMP-OXA-AMS-CTX-GEN-AMK- } \\
\text { ERYAZI- } \\
\text { CHL-TET-RIF-CLI-SXT-LNZ-VAN }\end{array}$ & $1(1.1 \%)$ \\
\hline & PVI b & $\begin{array}{l}\text { AMP-OXA-AMS-CTX-GEN-AMK- } \\
\text { ERYAZI- } \\
\text { CHL-CIP-RIF-CLI-SXT-LNZ-VAN }\end{array}$ & $1(1.1 \%)$ \\
\hline \multicolumn{4}{|c|}{$\begin{array}{l}\text { *AMP: Ampicillin; OXA: Oxacillin; AMS: Ampicillin/Sulbactam; CTX: Cefotaxime; } \\
\text { GEN: Gentamycin; AMK: Amikacin; ERY: Erythromycin; AZI: Azithromycin; CHL: } \\
\text { Chloramphenicol; TET: Tetracycline; CIP: Ciprofloxacin; RIF: Rifampicin; CLI: } \\
\text { Clindamycin; SXT: Sulphamethoxazole/Trimethoprime; LNZ: Linezolid; VAN: } \\
\text { Vancomycin. }\end{array}$} \\
\hline
\end{tabular}

Table 1: Antimicrobial resistance patterns of VRS isolates.

\section{Detection of vancomycin resistance determinants (van genes) by PCR}

The selected staphylococci isolate for PCR studies were representatives from each vancomycin MICs ranging from 2 to 512 $\mu \mathrm{g} / \mathrm{ml}$. Traditional PCR was performed on total DNA extract of each selected isolate for detection of $\operatorname{van} A, \operatorname{van} B$ and $\operatorname{van} C$ genes. The 
Citation: El-Said El-Banna T, Sonbol FI, Abd El-Aziz AA, El-Ekhnawy E (2018) Prevalence and Antimicrobial Susceptibility of Vancomycin Resistant Staphylococci in an Egyptian University Hospital. J Med Microb Diagn 7: 272. doi:10.4172/2161-0703.1000272

Page 5 of 8

amplified products were electrophoresed, and the resultant gels were stained by ethidium bromide and the amplicons were visualized using UV-transilluminator. Bands with approximate size of $1032 \mathrm{bp}$ for vanA gene, $647 \mathrm{bp}$ for $\operatorname{van} B$ gene and $815 \mathrm{bp}$ for $\operatorname{van} C$ gene were detected as illustrated in Figures 3. vanA gene was detected in 5 out of the 9 isolates with MICs ranging from 32 to $512 \mu \mathrm{g} / \mathrm{ml}$, where $\operatorname{van} B$ and vanC genes were absent in all the tested isolates.

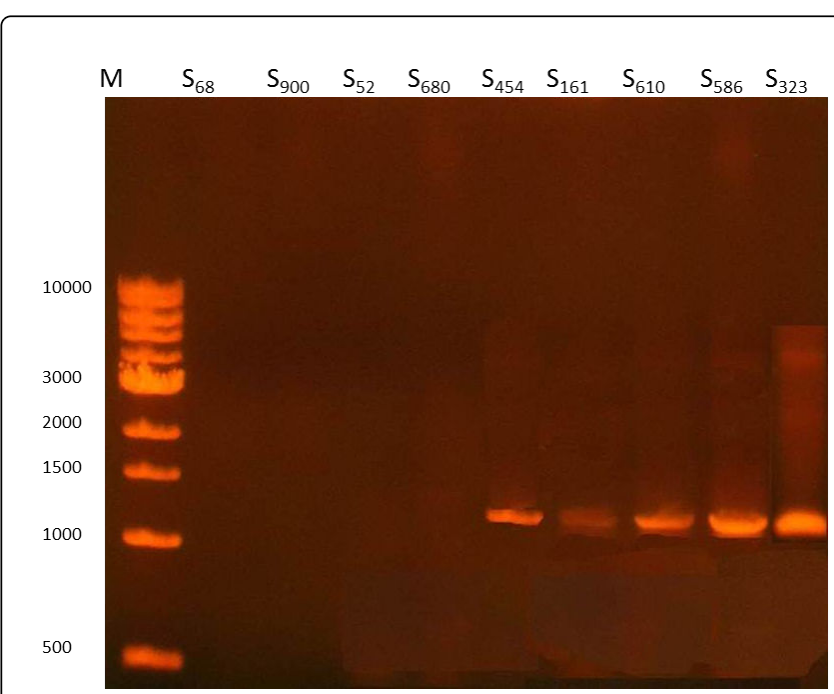

Figure 3: Electrophoregram of vanA gene amplicon. Lane $M$ was 1 $\mathrm{kb}$ DNA ladder. vanA gene was detected in 5 out of the 9 isolates with MICs ranging from 32 to $512 \mu \mathrm{g} / \mathrm{ml}$ (VRS) and was absent in isolates with MIC ranging from 2 to $16 \mu \mathrm{g} / \mathrm{ml}$ (VSS).

\section{Detection of $\beta$-lactamase production}

All VRS isolates were resistant to ampicillin therefore; they were screened for production of $\beta$-lactamase enzymes using iodometric overlay method. $\beta$-lactamase producers were detected by the formation of clear zones visualized around their growth in dark blue background of the medium. It was found that 79 out of the 89 VRS isolates $(88.7 \%)$ produced $\beta$-lactamase enzyme.

\section{D-test}

VRS isolates resistant to erythromycin and sensitive to clindamycin were selected for this test. Out of 29 isolates on which the test was performed, $24(82.8 \%)$ tested positive which appeared as flattening of clindamycin zone of inhibition adjacent to erythromycin disk.

\section{Efflux in ciprofloxacin resistant VRS isolates}

The ciprofloxacin resistant VRS isolates were selected for this test. The MICs of ciprofloxacin and ethidium bromide against the selected isolates were determined. All tested isolates showed MIC values ranged between 16 and $512 \mu \mathrm{g} / \mathrm{ml}$. On the other hand, the MIC for the sensitive control strain (S29231) was $<0.5 \mu \mathrm{g} / \mathrm{ml}$ for both tested agents.

Reserpine (efflux inhibitor) was used to study its effect on MICs of ciprofloxacin and ethidium bromide. It was found that reserpine decreased the MICs by 7-10-fold changing it to the sensitive range as shown in Table 2 in supplemental information.

\begin{tabular}{|c|c|c|c|c|}
\hline \multirow{3}{*}{$\begin{array}{l}\text { Tested } \\
\text { isolates }\end{array}$} & \multicolumn{4}{|c|}{ MIC $(\mu \mathrm{g} / \mathrm{ml})$ for isolates } \\
\hline & \multicolumn{2}{|c|}{ Ciprofloxacin } & \multicolumn{2}{|c|}{ Ethidium bromide } \\
\hline & -Reserpine* & +Reserpine & -Reserpine & +Reserpine \\
\hline S586 & 512 & 0.25 & 256 & 1 \\
\hline S555 & 512 & 0.25 & 256 & 0.5 \\
\hline S623 & 512 & 0.25 & 128 & 0.5 \\
\hline S144 & 256 & 0.25 & 256 & 0.25 \\
\hline S454 & 256 & 2 & 256 & 1 \\
\hline S650 & 256 & 1 & 128 & 1 \\
\hline S340 & 256 & 1 & 128 & 0.5 \\
\hline S313 & 256 & 4 & 64 & 2 \\
\hline S443 & 256 & 2 & 64 & 1 \\
\hline S141 & 256 & 2 & 32 & 1 \\
\hline S360 & 256 & 2 & 8 & 0.25 \\
\hline S140 & 128 & 2 & 128 & 2 \\
\hline S388 & 128 & 1 & 64 & 2 \\
\hline S618 & 128 & 1 & 64 & 2 \\
\hline S159 & 128 & 1 & 32 & 0.5 \\
\hline S155 & 64 & 0.5 & 64 & 0.5 \\
\hline S138 & 64 & 2 & 32 & 0.25 \\
\hline S323 & 64 & 1 & 16 & 0.5 \\
\hline $\mathrm{S} 29231^{* *}$ & 0.25 & 0.25 & 0.25 & 0.25 \\
\hline
\end{tabular}

Table 2: MICs of ciprofloxacin and ethidium bromide in presence and absence of reserpine.

The efflux of ethidium bromide by ciprofloxacin resistant VRS isolates was determined by measurement of fluorescence using spectrofluoremeter over $6 \mathrm{~min}$ experimental time. The effect of reserpine on ethidium bromide efflux by ciprofloxacin resistant VRS isolates was studied and a representative line chart of the result is shown in Figure 4. Ethidium bromide fluorescence didn't change over the time course of the experiment in case of $S$. aureus reference strain (control) (A). On the other hand, marked decrease of fluorescence was observed in case of other staphylococci isolates (B). This decrease was inhibited in presence of $20 \mu \mathrm{g} / \mathrm{ml}$ reserpine (C). 


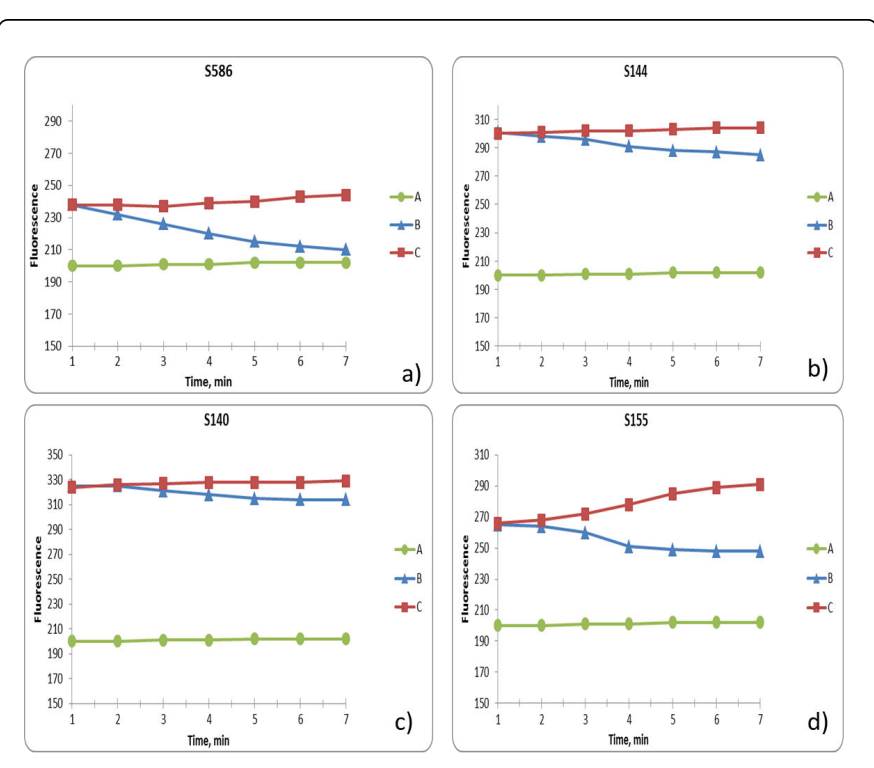

Figure 4: Effect of reserpine on ethidium bromide efflux by: a) S586 isolate with ciprofloxacin $\mathrm{MIC}=512 \mu \mathrm{g} / \mathrm{ml}$. b) S144 isolate with ciprofloxacin MIC $=256 \mu \mathrm{g} / \mathrm{ml}$. c) S140 isolate with ciprofloxacin $\mathrm{MIC}=128 \mu \mathrm{g} / \mathrm{ml}$. d) S155 isolate with ciprofloxacin MIC=64 $\mu \mathrm{g} / \mathrm{ml}$.

\section{Discussion}

All the recovered (437) staphylococci isolates were subjected to disk agar diffusion method for preliminary screening of vancomycin resistance. Out of these, $89(20.36 \%)$ VRS isolates were detected. This finding was comparable to the percentage reported by Ghoniem [13] in Egypt which was $20.68 \%$ and lower than the percentages reported by many authors [14] 76.9\% in South Africa; [15] 37\% in Iran; [16] 30\% in Saudia Arabia and [17] 26.67\% in India. On the other hand, this finding was higher than that reported by Olivo et al. [18] in Brazil and Moses et al. [19] in Nigeria which were $9.3 \%$ and 5.4\%, respectively. The relatively high rates of VRS isolates in this study could be partially explained by a selection pressure induced by an inadequate use of antimicrobials [20]. It was found that out of the tested 89 VRS isolates there were $88 S$. aureus $(98.88 \%)$ and only one isolate (1.12\%) was $S$. epidermidis. [21] reported that $100 \%$ of VRS were $S$. aureus. However, vancomycin resistant $S$. epidermidis was reported by Sanyal and Pienheiro [22,23]. The glycopeptide antibiotic vancomycin is often the sole remaining antibiotic active against staphylococcal infections. As such, the acquisition of glycopeptide resistance by staphylococci has been anticipated with apprehension [24-27]. In our study, the results of disk diffusion test for determination of vancomycin resistance were in accordance with that of agar dilution as 89 VRS isolates were detected in either of them. In this study, 231(52.86\%) isolates were VSS (MIC $\leq$ $4 \mu \mathrm{g} / \mathrm{ml}$ ), 117 (26.77\%) were VIS (MIC 8-16 $\mu \mathrm{g} / \mathrm{ml}$ ) and 89 (20.36\%) were VRS isolates (MIC $\geq 32 \mu \mathrm{g} / \mathrm{ml}$ ). [13] reported that $67 \%$ of Staphylococci isolates were VSS, $12 \%$ were VIS and $21 \%$ were VRS. On the other hand Tiwari and Sen [24] reported that $86 \%$ of staphylococci isolates were VSS, 9.3\% were VIS and $4.7 \%$ were VRS. The emergence of vancomycin resistance in staphylococci isolates has wide implications for the clinicians as this will increase the morbidity and mortality rate due to VRS infections. Susceptibility testing to other antimicrobials was performed to identify which one may be expected to have useful activity against VRS to help in the management of the infections caused by these isolates. So, the susceptibility of VRS isolates to 15 antimicrobial agents was carried out in the present study. Interestingly, all these VRS isolates showed resistance to a minimum of 10 antimicrobials including vancomycin, a finding that is comparable to what was detected by Adigoke [14] which was 9 antimicrobials including vancomycin. Also, Thati et al. [24] found that all VRS isolates were resistant to at least six antimicrobials other than vancomycin. All VRS isolates in the present work were MDR isolates and this phenomenon of multiresistance among VRS isolates was also reported by several authors [13,24-27]. In general, the problem of antimicrobial resistance has multiple implications with respect to outcomes. Persons infected with multiresistant VRS may face higher mortality rates [28]. This is partially due to the fact that infection with multiresistant VRS isolates is associated with the risk for initially inappropriate antimicrobial therapy, a major determinant of patient survival in serious infections $[28,29]$. Moreover, the high risk for death may reflect that multiresistant VRS have more virulence factors. Beyond mortality, resistant pathogens contribute to escalating hospital costs $[28,29]$. All isolates $(100 \%)$ were resistant to ampicillin and cefotaxime followed by ampicillin/sulbactam (88.8\%) and oxacillin (87.6\%). Sulphamethoxazole/trimethoprime (cotrimoxazole) and linezolid showed the least incidences of resistance, where only $43.8 \%$ and $37 \%$ of the VRS isolates, respectively, were resistant to them. A finding which is also reported by many other authors in this field $[13,25]$. Therefore, these drugs could be used for therapy of these infections. However, until more experience exists, the best treatment strategy would appear to be to tailor therapy based on the susceptibility of the isolate in each case.

Detection of van genes in the tested isolates was performed using PCR technique. The selected isolates were representatives for each vancomycin MICs ranging from 2 to $512 \mu \mathrm{g} / \mathrm{ml}$. Band of van $A$ gene (1032 bp) was detected in VRS isolates only and it wasn't found neither in VSS nor VIS isolates. On the other hand, bands of $\operatorname{vanB}(647 \mathrm{bp})$ and $\operatorname{van} C(815 \mathrm{bp})$ genes were absent in all tested isolates. [24] reported that out of 7 VRS isolates, 6 (85.7\%) contained van $A$ gene and didn't contain neither the $\operatorname{van} B$ nor $\operatorname{van} C$ genes and El-Daker [21] reported that $100 \%$ of VRS isolates possessed $\operatorname{van} A$ gene only. On the other hand, Tiwari and Sen [30] reported van genes-negative VRS isolates.

Resistance mechanisms to some other antimicrobials were studied including $\beta$-lactamase production, detection of inducible clindamycin resistance mediated by erm gene using the disk approximation test (Dtest) and the efflux mechanism of resistance. Liang et al. [31] in his study on staphylococci, reported that one of the important mechanisms of resistance to $\beta$-lactams was the expression of $\beta$ lactamases which hydrolyze $\beta$-lactam ring of penicillins and cephalosporins, thereby making these antimicrobials inactive [32]. In the present study, $88.7 \%$ of staphylococci isolates were $\beta$-lactamase producers using iodometric overlay method. This percentage was higher than that reported by Arslan and Ozkarde et al. [33] in Brazil and Gad et al. [34] in Egypt which were 74.4\% and 55\%, respectively.

Clindamycin resistance is either constitutive or inducible following exposure to a macrolide. Induction tests (D-test) utilize closely approximated erythromycin and clindamycin disks; the flattening of the clindamycin zone of inhibition adjacent to the erythromycin disk indicates inducible clindamycin resistance [10]. In the present study, detection of inducible clindamycin resistance using the disk approximation test (D-test) was performed on all VRS isolates that were resistant to erythromycin and sensitive to clindamycin. This test 
appears to be a reliable indicator of the presence of erm gene which encodes enzymes that confer inducible resistance to lincosamides (clindamycin) by methylation of the 23S rRNA [10]. Out of 29 isolates on which the test was performed, $24(82.8 \%)$ tested positive. Higher result was reported by Thati et al. [24] who found that $100 \%$ of the isolates exhibited inducible clindamycin resistance. On the other hand, lower results were reported by Rice and Sexena et al. [35,36] where they found that only $18.6 \%$ and $25.8 \%$, respectively of isolates had inducible clindamycin resistance.

Fluoroquinolone antibiotics are important class of antimicrobials that exhibit a broad spectrum of antibacterial activity [37]. The efflux of fluoroquinolones and the expression of multidrug transporters have been demonstrated for staphylococci, in which the major role in fluoroquinolone efflux is done by the membrane transporter NorA [38]. NorA promotes the active efflux of a wide variety of organic compounds like ethidium bromide with fluoroquinolone antibiotics being one of the best transporter substrates [38]. In fact, reserpine was discovered to reverse NorA-mediated drug resistance [39] so it was used as efflux inhibitor.

In this work, the efflux mechanism in 18 ciprofloxacin resistant VRS isolates was studied using fluorometric assay. Efflux mechanism was detected in all of these isolates where they showed accumulation of the fluorescent dye ethidium bromide inside the cells that remained relatively higher when the cells treated with the efflux inhibitor reserpine. Reports of Mullin et al. and Gadd et al. [11,34] involved fluorimetric method to study the efflux mechanism of resistance and the effect of reserpine on the accumulation of ethidium bromide in VRS isolates.

\section{Conclusion}

Finally, the findings of this study indicated that infection by VRS isolates has started to spread in Tanta area as up to $20.4 \%$ of staphylococci isolates were VRS. It also appears that there are few treatment options for VRS infections because they tend to be multi drug resistant against a large number of currently available antimicrobial agents. The VRS isolates exhibited resistance to antimicrobials through several ways indicating that different resistance mechanisms may interact to increase the level or spectrum of resistance of such organisms.

\section{References}

1. Srinivasan A, Dick JD, Perl TM (2002) Vancomycin resistance in staphylococci. Clin Microbiol Rev 15: 430-438.

2. Roberts S, Chambers S (2005) Diagnosis and management of $S$. aureus infections of the skin and soft tissue. Intern Med J 35: 97-105.

3. Hiramatsu K, Aritaka N, Hanaki H, Kawasaki, S, Hosoda, Y, et al (1997) Dissemination in Japanese hospitals of strains of Staphylococcus aureus heterogeneously resistant to vancomycin. Lancet 350:1670-1673.

4. Kollef MH, Micek ST (2005) Strategies to prevent antimicrobial resistance in the intensive care unit. Crit Care Med 33:1845-1853.

5. Kloos WE, Lambe DW (1991) Staphylococcus in: Manual of Clinical Microbiology. Balows WJ 222-237.

6. Clinical and Laboratory Standards Institute (CLSI) (2016) Performance standards for antimicrobial susceptibility testing; twenty-seven informational supplements. Wayne, Pennsylvania, USA.

7. Abd El-Baky RM, Ahmed HR, Gad GF (2014) Prevalence and conjugal transfer of vancomycin resistance among clinical isolates of Staphylococcus aureus. AIR 2:12-23.
8. Bhatt P, Sahni AK, Praharaj AK, Grover N, Kumar M, et al (2015) Detection of glycopeptide resistance genes in staphylococci by multiplex PCR. MJAFI 71: 43-47.

9. Abo-Kamar A, Shohayeb M (1998) An iodometric overlay method for detection and preliminary typing of $\beta$-lactamases. Al-Azhar J Microbiol 42: 72 .

10. Fiebelkorn KR, Crawford SA, Mcelmeel ML, Jorgensen JH (2003) Practical disk diffusion method for detection of inducible clindamycin resistance in Staphylococcus aureus and coagulase-negative staphylococci. J Clin Microbiol 41: 4740-4744.

11. Mullin S, Mani N, Grossman TH (2004) Inhibition of antibiotic efflux in bacteria by the novel multidrug resistance inhibitors Biricodar (VX-710) and Timcodar (VX-853). Antimicrob Agents Chemother 48: 4171-4176.

12. Magiorakos AP, Srinivasan A, Carey RB, Carmeli Y, Falagas M, et al. (2012) Multidrug-resistant, extensively drug-resistant and pandrugresistant bacteria: An international expert proposal for interim standard definitions for acquired resistance. Clin Microbiol Infect 18:268-281.

13. Ghoniem EM, El Hendawy GR, Abdel Moteleb TM, Hassan HA, Khalil AE (2014) Characterization of vancomycin-resistant Staphylococcus aureus in the National Liver Institute. Menoufia Med J 27:825-832.

14. Adegoke AA, Okoh AI (2011) The in vitro effect of vancomycin on multidrug resistant Staphylococcus aureus from hospital currency notes. Afr J Microbiol Res 5: 1881-1887.

15. Saadat S, Solhjoo K, Norooz-Nejad MJ, Kazemi A (2014) vanA and vanB positive vancomycin-resistant Staphylococcus aureus among clinical isolates in Shiraz, South of Iran. Oman Med J 29:335-339.

16. Alzolibani AA, Al Robaee AA, Al Shobaili HA, Bilal JA, Ahmad MI, et al (2012) Documentation of vancomycin-resistant Staphylococcus aureus (VRSA) among children with atopic dermatitis in the Qassim region, Saudi Arabia. Acta Dermatovenerol APA 21:51-53.

17. Chakraborty SP, Mahapatra SK, Bal M, Roy S (2011) Isolation and identification of vancomycin resistant Staphylococcus aureus from postoperative pus sample. Al Ameen J Med Sci 4: 152-168.

18. Olivo T, Carvalho de Melo E, Rocha C, Fortaleza CM (2009) Risk factors for acquisition of methicillin-resistant Staphylococcus aureus among patients from a burn unit in Brazil. Burns 35:1104-1111.

19. Moses A, Uchenna U, Nworie O (2013) Epidemiology of vancomycin resistant Staphylococccus aureus among clinical isolates in a tertiary hospital in Abakaliki, Nigeria. AJEID 1:24-26.

20. Abbanat D, Macielag M, Bush K (2008) New agents in development for the treatment of bacterial infections. Current Opin Pharma 8:582-92.

21. El-Daker MA, Mesbah MR, El-Naggar MM, Khalil EA, El-Kenawy MF (2008) The first two vancomycin resistant $S$. aureus isolates in Mansoura university hospital; epidemiology and antimicrobial study. EJMM 17:31-43.

22. Sanyal D, Johnson AP, George RC, Cookson BD, Williams AJ (1991) Peritonitis due to vancomycin-resistant S. epidermidis. Lancet 337:54.

23. Pinheiro L, Brito CI, Pereira VC, de Oliveira A, Camargo CH, et al (2014) Reduced susceptibility to vancomycin and biofilm formation in methicillin-resistant Staphylococcus epidermidis isolated from blood cultures. Mem Inst Oswaldo Cruz 109: 871-878.

24. Thati V, Shivannavar CT, Gaddad SM (2011) Vancomycin resistance among methicillin resistant Staphylococcus aureus isolates from intensive care units of tertiary care hospitals in Hyderabad. Indian J Med Res 134: 704-708.

25. Wootton M, Howe RA, Walsh TR, Bennett PM, MacGowan AP (2002) In vitro activity of 21 antimicrobials against vancomycin-resistant $S$. aureus (VRSA) and hetero-VRSA (hVRSA). Antimicrob Agents Chemother 50:760-761.

26. Hakim ST, Arshed S, Iqbal M, Javaid SG (2007) Vancomycin sensitivity of Staphylococcus aureus isolates from hospital patients in Karachi, Pakistan. Libyan J Med 2:176-179.

27. Saha B, Singh AK, Ghosh A, Bal M (2008) Identification and characterization of a vancomycin resistant $S$. aureus isolated from Kolkata (South Asia). J Medical Microbiol 57: 72-79. 
Citation: El-Said El-Banna T, Sonbol FI, Abd El-Aziz AA, El-Ekhnawy E (2018) Prevalence and Antimicrobial Susceptibility of Vancomycin Resistant Staphylococci in an Egyptian University Hospital. J Med Microb Diagn 7: 272. doi:10.4172/2161-0703.1000272

Page 8 of 8

28. Cosgrove SE, Qi Y, Kaye KS, Harbarth S, Karchmer AW, et al. (2005) The impact of methicillin resistance in Staphylococcus aureus bacteremia on patient outcomes: mortality, length of stay and hospital charges. Infect Control Hosp Epidemiol 26:166-174.

29. Shorr AF, Tabak YP, Gupta V, Johannes RS, Liu LZ, et al. (2006) Morbidity and cost burden of methicillin-resistant Staphylococcus aureus in early onset ventilator-associated pneumonia. Crit Care 10:97-111.

30. Tiwari HK, Sen MR (2006) Emergence of vancomycin resistant $S$. aureus (VRSA) from a tertiary care hospital from northern part of India. Infect Dis 6: 156.

31. Liang W, Huang H, Lin R, Hou W (2003) Screening for natural inhibitors of penicillinase by copolymerization of hydrolyzed starch or glycogen in sodium dodecylsulfate polyacrylamide gels for detecting penicillinase activity. Bot Bull Acad Sin 44:187-191.

32. Ekrem K, Meltem YC (2006) Comparison of Staphylococcal $\beta$-lactamase detection methods. J Pharm Sci 31:79-84.

33. Arslan S, Ozkarde F (2007) Slime production and antibiotic susceptibility in staphylococci isolated from clinical samples. Mem Inst Oswaldo Cruz 102: 29-33.
34. Gad FM, Abd El-Ghafar EF, El-Domany AA, Hashem ZS (2010) Epidemiology and antimicrobial resistance of staphylococci isolated from different infectious diseases. Brazil J Microbiol 41: 333-344.

35. Rice LB (2006) Antimicrobial resistance in Gram-positive bacteria. Am J Med 119: S11-S19.

36. Sexena S, Singh T, Rakshit P, Dutta R, Gupta R (2014) Prevalence of inducible clindamycin resistance in Staphylococcus aureus at a tertiary care hospital: implications for clinical therapy. Int J Curr Microbiol App Sci 3: 720-725.

37. Dalhoff A (2012) Global fluoroquinolone resistance epidemiology and implictions for clinical use. Interdisciplinary perspectives on infectious diseases 2012: 1-37.

38. Costa SS, Falcao C, Viveiros M, Machado D, Martins M, et al (2013) Exploring the contribution of efflux on the resistance to fluoroquinolones in clinical isolates of $S$. aureus. BMC Microbiol 13:127-132.

39. Neyfakh A, Borsch CM, Kaatz GW (1993) Fluoroquinolone resistance protein NorA of Staphylococcus aureus is a multidrug efflux transporter Antimicrob Agents Chemother 37:128-129. 